\title{
Design of Storm Water Drainage System to Enhance Ground Water Level-A Case Study on Hosur Inner Ring Road (IRR)
}

\author{
Dr.L. Yesodha, Dr.T. Meenambal and Er.KR. Manikandan
}

\begin{abstract}
Drainage of water from pavements has been an important consideration in road construction for more than 2000 years. However, modern processing, handling, and placement of materials frequently result in base courses that do not transmit water or drain; combined with increased traffic volumes and loads, this often leads to pavement distress caused by moisture in the structures. Water related damages on the pavement can cause one or more of the following forms of deterioration, (i) Reduction of sub-grade/sub-base strength
\end{abstract} (ii) Differential swelling in expansive sub-grade soils Stripping of asphalt in flexible pavement, etc., Free water is the form of most concern to the designer because it can decrease the strength of the pavement and is the only form of water that can be significantly removed by gravity drainage (Lytton et al., 1993). The present study is to investigate on storm water drainage system on Hosur-Inner Ring road and to Design the sub-surface drainage system. Study area was considered on Hosur-Inner ring road between ESI hospital and Anand Electronics ( $\mathrm{km} \mathrm{0/0} \mathrm{-} \mathrm{km} \mathrm{8/850).The} \mathrm{selected}$ stretch for our study was paved stretch $1 \mathrm{~km}(\mathrm{~km} \mathrm{6/100} \mathrm{to}$ 7/100) and unpaved stretch $1 \mathrm{~km}$ ( $\mathrm{km} \mathrm{7/155} \mathrm{to} \mathrm{8/155).}$ Geometrical characteristics of the road were analyzed about longitudinal and transverse profiles on both stretches and design of drainage system was done for unpaved stretch. The investigations were carried out by field surveys to obtain the sag points longitudinally and along the cross sections to determine their geometric properties. The primary source of water in pavements is atmospheric precipitation. This water can enter the pavement through several ways (e.g., cracks, infiltration, through shoulders and ditches, high groundwater) and is moved by an energy gradient, such as gravity, capillary forces, osmotic forces, and temperature or pressure differences. The drainage system is primarily concerned with saturated gravity flow, which can be determined by application of Darcys law. To understand and analyze the conditions under which the pavement must function, The information needs on highway geometrics, surface drainage, non-pavement subsurface drainage, climate, and soil properties. The details such as, Traffic data, Road Cross

Dr.L. Yeshodha, Professor, Department of Civil Engineering, Adhiyamaan College of Engineering, Hosur, India. E-mail:yesocivil.123@gmail.com

Dr.T. Meenambal, Professor, Department of Civil Engineering, Government College of Technology, Coimbatore, India. E-mail: tmeenambal_gct@yahoo.co.in

Er.KR. Manikandan, Assistant Engineer, Department of Quality Assurance and Quality Control, Sai Care India Private Limited, Chennai, India. Email:belleyedancivilian.1793@gmail.com DOI: 10.9756/BIJIEMS.8034 sectional details and Rainfall data for last 10-year, were collected from Highways Department and Taluk office, Hosur respectively and the laboratory tests on sub-grade material was conducted on three soil samples collected at every $300 \mathrm{~m}$ interval at a depth of $1 \mathrm{~m}$ below the earth surface. Laboratory investigations included determination of Gradation, Natural Moisture Content (NMC),Optimum Moisture Content (OMC), Maximum Dry Density (MDD), and Permeability (K). From the above soil tests it was observed that, the soil type is well-graded soil. The nature of soil is semi-pervious and the drainage property of the soil is Excellent. Based on the geometrics of road and natural properties of soil, the sub-surface drainage system was designed for selected stretch considering Hydraulic and Hydrological parameters. Several combinations of criteria and equations were selected to calculate the required permeability of the drainage layer. The criterion selected has much more influence than the equation used; therefore, the drainage criterion should be selected and calculated with the aid of Nomographs, Family and Group curves. These data enable the designer to predict the amount of free water that will enter the pavement structure, to predict the free water surface. The free water can be removed by draining vertically through the subgrade or laterally through a drainage layer. Then the drainage layer and collector trenches components were designed to meet the selected criterion. Perforated Corrugated Pipe (Geo-Rex-Plus pipe-A modern polymer pipe), was used in design of drainage system to collect the runoff from the pavement surface into collector trench leading to the recharge trench at the outlet, to enhance the Ground Water Level.

Keywords--- Ground Water Recharge, Hydraulic Analysis, Hydrological Parameter, Perforated-Corrugated Drains and Sub-surface Drainage System

\section{INTRODUCTION}

$\mathrm{T}$ HE studies performed to formulate these design have demonstrated that most modern highway pavement; structural sections are slow draining systems, and heavy wheel impacts on these structural sections that contain free water or excess water are accelerating the damage and deterioration of the highways. Subsurface drains have generally been used to remove high ground water, inflows from springs, etc; but seldom used specifically for the control of surface water that infiltrates into the highway pavement 
structural sections. The purpose of the case-study is to show how to design drainage layers to rapidly drain entire roadbeds to reduce the periods of exposure of structural sections to excess water. The basic method considers subsurface drainage layers as conveyors of water and analyzes probable inflow rates from all known important sources. Seepage principles are then used to determine the required permeability and thickness of a sub- surface drainage layer that will accommodate the anticipated flows. The present study was taken to design proper sub surface drainage system which can reduce the run off and can enhance the ground water level.

\section{A. Why SSDs Needed for Hosur IRR}

Hosur is an industrial town in Krishnagiri District of Tamilnadu State, situated $40 \mathrm{Kms}$ from Bangalore. It is a town with several major industries like Titan, Ashok Leyland, TVS and many small scale industries located in and around Hosur, Due to increase in population and industrialization, transportation facilities to be increased to carry men and material. Hence, it is essential to provide inner ring road to connect various location in and around Hosur. Hence it is proposed to construct a Hosur-Inner Ring Road. To properly protect highway pavement structural sections needs, subsurface drains must be capable of removing the water as fast as it enters. Since the present Case study deals with design of sub-surface drainage system for $1 \mathrm{~km}$ unpaved selected stretch to reduce the run-off entry into pavement structural sections and mean while enhances the ground water level for designed length of the stretch.

\section{B. Objectives of Our Study}

1. To design the geometric parameter of the road.

2. To study the soil characteristics of sub-grade.

3. To design a suitable sub-surface drainage system to increase groundwater table with Hydraulic and Hydrological parameters.

\section{Study Area Details}

The study area for our present study was selected on the Hosur Inner Ring Road, HosurTaluk, Krishnagiri district, Tamilnadu. The Hosur town located about $45 \mathrm{~km}$ from Bangalore city. It lies between a latitude of $12^{\circ} 7^{\prime}-12^{\circ} 44^{\prime} \mathrm{N}$ and longitude of $77^{\circ} 30^{\prime}-78^{\circ} 27^{\prime} \mathrm{E}$ occupying an area of about 72 sq.km. The location of our study starts from Hosur ESI hospital to Anand electronics on NH-7 about $8.850 \mathrm{~km}$. About $1 \mathrm{~km}$ stretch on paved surface and $1 \mathrm{~km}$ stretch on unpaved surface was selected for our investigation .The paved stretch of $1 \mathrm{~km}$ were selected to analyze cross slope and geometry of the stretch. The unpaved stretch of $1 \mathrm{~km}$ were selected to study the soil characteristics and to design the sub-surface drainage system which consists Horizontal curve (km 7/100 to

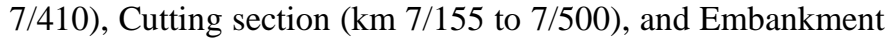
section $(\mathrm{km} \mathrm{7/550}$ to 8/155) in each category. Figure 1 \& Figure 2 shows the details of study area map. The detailed cross section of the selected stretches of Hosur Inner Ring Road is as shown in Figure 3

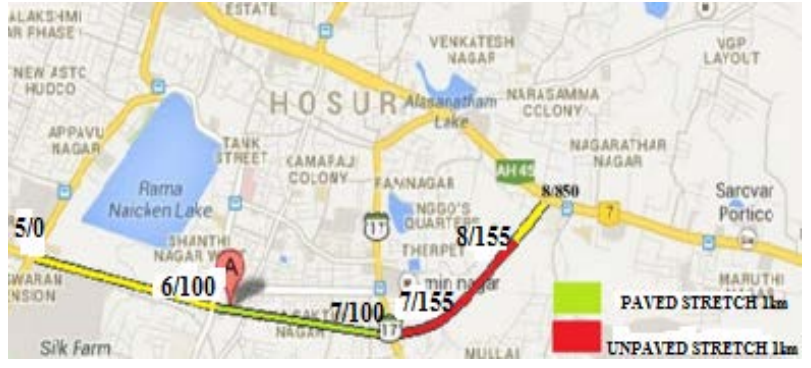

Fig. 1: Map showing Hosur Inner Ring Road

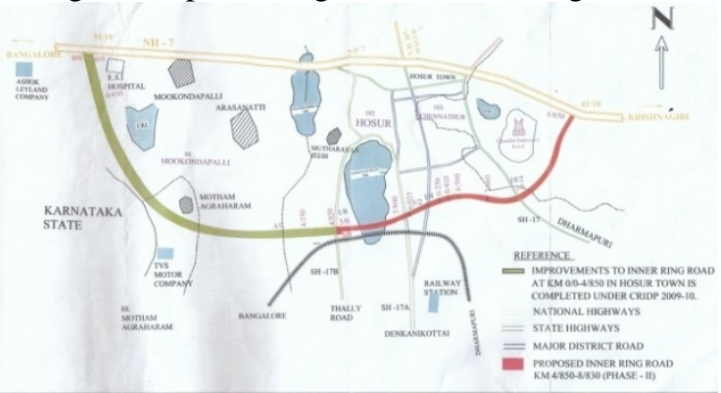

Fig. 2: Map Showing the Details of Study Area
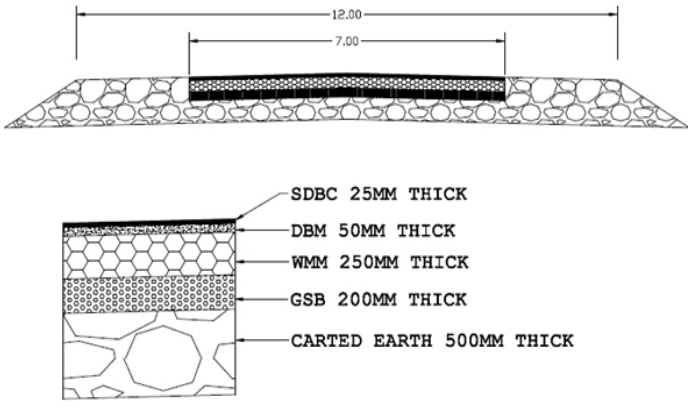

Fig. 3: Typical Cross Section of the Pavement

\section{LITERATURE SURVEY}

About over sixty valuable materials, which includes guidelines, project reports, lectures and papers published by various authors, have been employed in this research work as a reinforcing input. Some of those outcomes of the materials were discussed here.

Results from laboratory and field tests conducted on a number of roads indicated that the moduli of base and subgrade materials were strongly affected by moisture content (Yuan et al., 2003). Furthermore, a relatively rapid decrease in the level of serviceability could occur, because the pavement ability to transmit dynamic loads imposed by the traffic would be greatly weakened (Moulton, 1980 and Tangpithakkul, 1997). Movement of the wheel on a pavement with a saturated subgrade can produce a moving pressure wave, which in turn can create large hydrostatic forces within the structural section. These pulsating pore pressures significantly influence the load-carrying capacity of all parts of the pavement structure (Cedergren, 1974). The freeze-thawcycles could also cause moisture-induced pavement damage, because the moisture will migrate through the capillary fringe toward the freezing front to increase ice lenses. 
Cedergren(1988) evaluated early field tests that includedbothdrainedandundrainedsections(WASHOtest1955; AASHOtest1962;UniversityofIllinoistest1970).Basedonthesefi elddata,heestimatedthatafloodedundrainedpavementexperience s10to70,000 times the damage from aloadevent compared to adrainedpavement.

Forsyth et al. (1987) presented a number of case studies related to pavement drainage. They report that the use of edge drains usually improve the durability of pavements. Forsyth et al. concluded that the percentage of cracked slabs in the undrained sections exceeds that in the drained sections by a ratio of 2.4 to 1 .

\section{MATERIALS AND METHODS}

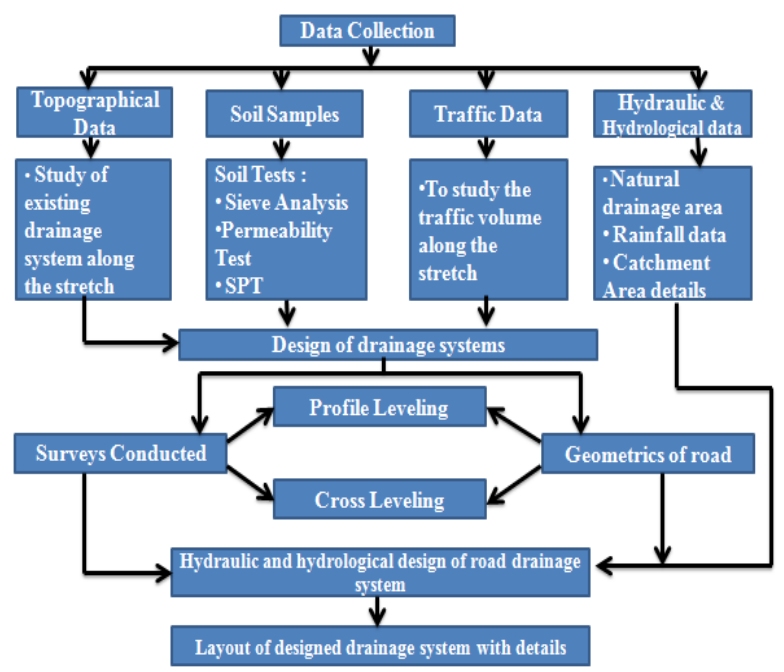

Fig. 4: Flow Chart Depicting the Methodology

Detailed methodology of study shown in Figure 4. To study and design the storm water drainage system, existing topographical status of drainage system was studied to identify various problems related to drainage system. Traffic data was collected from Highways Department, Hosur. Soil samples were collected from $1 \mathrm{~m}$ below the sub-grade on unpaved stretch at $300 \mathrm{~m}$ intervals. Rainfall data obtained from Hosur Taluk office for a period of 10 years from 2002-2012.

The collected samples were analyzed in the laboratory and field surveys were conducted. Hydraulic and Hydrological parameters were considered for Design of drainage system.

\section{A. Field Surveys Conducted}

Field surveys were conducted to plot the longitudinal and cross-sectional details on the paved and unpaved stretch. Figure 11, 12, 13 \& 14 shows the Longitudinal Sectioning and Cross- Sectioning of paved and unpaved stretches. Table II shows the details of gradient on paved and unpaved surfaces.

\section{B. Laboratory Tests on Soils}

To analyze the soil characteristics, soil samples were collected from sub-surface was tested to determine the Natural Moisture Content (NMC), Gradation, Specific Gravity (G), Optimum Moisture Content (OMC) \& Maximum Dry Density
(MDD) and Permeability. The test results were analyzed and various properties of sub-grade material was also described as shown in Table III

\section{Selection of Equations for Hydraulic and Hydrological Design of Subsurface Drainage System}

The main principles or concepts are as follows

a. Darcy's law for laminar flow is adequate for the design of subsurface drainage systems.

b. Subsurface drainage systems will only drain free water from a pavement structure.

c. The primary source of free water to the pavement structure is infiltrated water.

d. Permeability requirements for lateral flow are very high because the hydraulic gradient is very low and the area of the flow is small.

e. Proper filters need to be included if the drainage system is to function properly for a long period of time.

f. The permeability of the subgrade material and the location of the free water surface (water table) must be known if removal of the free water by vertical flow is to be investigated.

\section{Selected Equations for both Cutting \& Embankment Portion}

The permeability capacity of sub-grade soil determined from laboratory test to get the hydraulic gradient (i) of ground water inflow, and assume Darcy's law is valid,(if, section is in cutting portion)

$$
Q=k i a
$$

Where, $\mathrm{Q}=$ discharge per unit length, $\mathrm{i}=$ hydraulic gradient, $\mathrm{k}=$ co-efficient of permeability, $\mathrm{a}=$ cross sectional area of the soil. The 1 hour / 1year precipitation rate from last 10-year rainfall data in inches/hour were needed then it should be computed with respective manner or taken from country's meteorological map. Assume the $95 \%$ of run-off can be drained into sub-surface drains ( i.e., I= infiltration on the open graded base is, 0.95 times precipitation rate).Then the equation required to compute ground water inflow per square feet of sub-grade surfaces is,

$$
k_{s} \times i \text { (if, section is in cutting portion). (2) }
$$

Get ground water infiltration to surface infiltration is,

$$
I^{\prime}=I+\left(k_{S} \times i\right)(3)
$$

Where, I'=estimated or design infiltration rate on the open graded base.

Thickness of drainage layer was selected from Infiltration curve chart, shown in Figure 5,

$$
c=k_{b} \times t_{b}
$$

Where, $\mathrm{k}_{\mathrm{b}} \& \mathrm{t}_{\mathrm{b}}$ are permeability \& thickness of drainage layer in , ft/day, \& inches and w \& s are total width in $\mathrm{ft}$ or cross slope of pavement. 


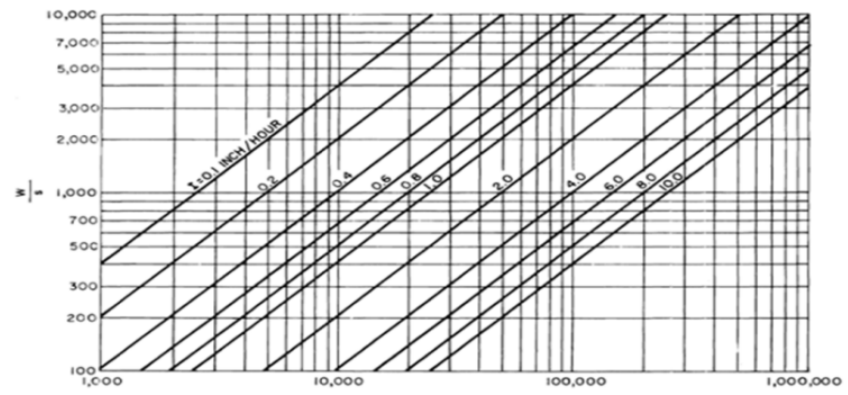

Coefficient of Transmissibility c-inch feet/ day

Fig. 5: Graph between Coefficient of Transmissibility versus $\mathrm{w} / \mathrm{s}$

Get correct thickness of drainage layer select a family curve of permeability of drainage layer with various thickness of drainage layer and compute the final thickness with selected permeability of drainage layer. The family curve is shown in Figure. 6,

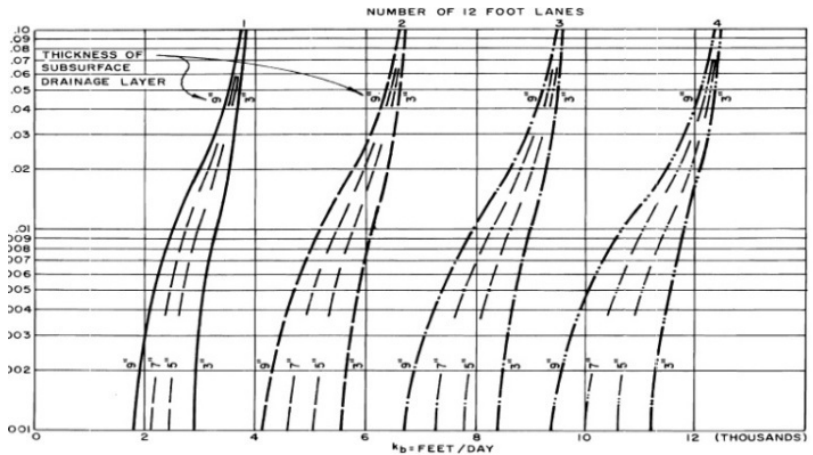

Fig. 6: Permeability Required in Order to Subsurface Drainage Layer in 1 Hour or Less

$$
t_{b}=\left(c / k_{b}\right)+1
$$

The actual permeability of the drainage layer with satisfies the condition of T(time to drain) is less than 1-hour. Select the $k_{b}$ value from graph of $k_{b}, t_{b}$, g(longitudinal gradient) \& number of 12 foot lanes.

The required permeability of drainage layer $k^{\prime}{ }_{b}=k_{b} / T$ when $\mathrm{T}$ less than 1 hour were computed through time to drain of drainage layer,.

$$
T=\frac{24 \times w \times n_{b}}{\left[k_{b} \times\left(\frac{s+t_{b}}{\left[24 \times w \times\left(1+y^{2}\right)\right]}\right)\right]}
$$

Where, $n_{b}=$ effective porosity of open graded base, $20 \%$. And $\mathrm{y}=\mathrm{g} / \mathrm{s}$.

The perforated pipe diameter and outlet spacing was selected using nomograph shown in Figure. 7 with the available and assumed parameters of design infiltration rate, width of the pavement \& suitable pipe gradient.

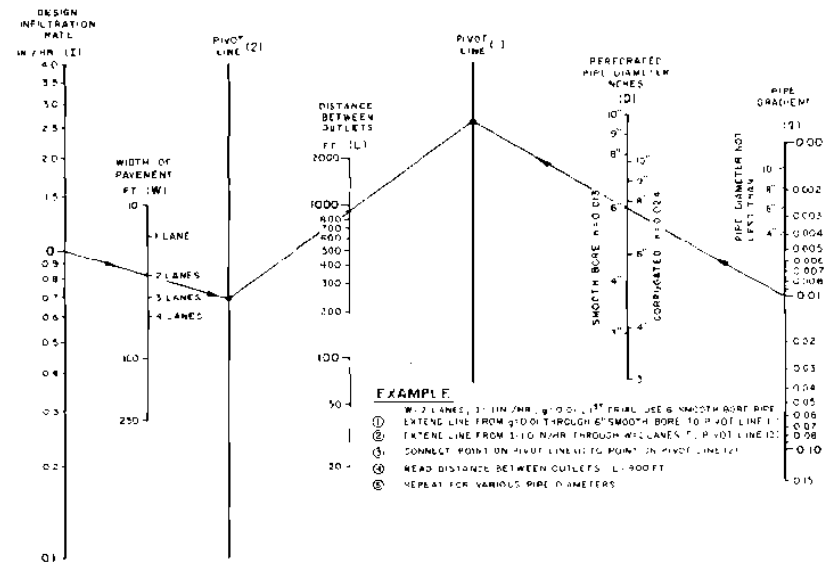

Fig. 7: Nomograph for Selection of Perforated Pipe Diameters and Outlet Spacing

To determine the collector pipe trench width (B) \& permeability of trench backfill $\left(\mathrm{k}_{\mathrm{t}}\right)$, using the graph of number of 12 foot lanes \& B- $\mathrm{k}_{\mathrm{t}}$ with design infiltration lines shown in, Figure. 8.

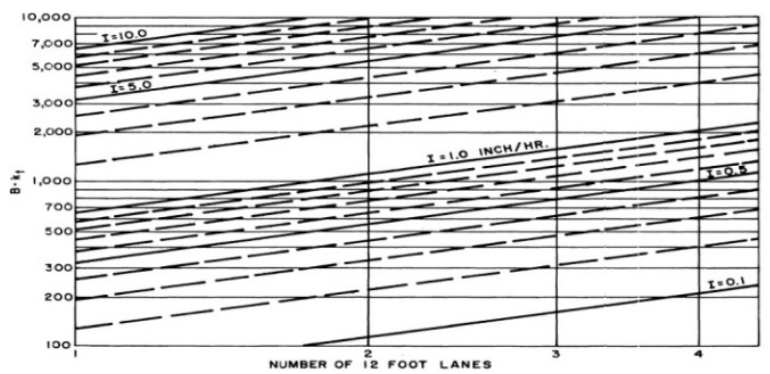

Fig. 8: Chart to Determine Either Required Collector Pipe Trench Backfill Permeability or Collector Pipe Trench width

Normally the collector trench widh should be, $\mathrm{B}=$ ( outside diameter of perforated pipe, in $\mathrm{mm}+150 \mathrm{~mm}+$ 150mm)

From this to determine the value of, $\mathrm{k}_{\mathrm{t} .}$ Then Bactual is,

$$
B_{\text {actual }}=\frac{40 \times I \times w}{k_{t}}(7)
$$

\section{Design Steps for Super Elevated Portion}

For super elevated curves, collector drains should be installed along the lower side of the curve, and cross collector drains should be in- stalled whatever required to prevent the "build-up" of a hydrostatic head in the drainage layer in excess of the overburden pressure. Hence, the below mentioned points should be kept in a mind while designing SSDs in a Horizontal curve portion. Here we design the longitudinal drain for full super elevated section. At least minimum of 6 points were designed at inner side of the curve, i.e., Beginning and end of curve on $0.00,-0.01$ and -0.02 cross slopes. The design steps are same for here to determine all parameters. If, the section is in cutting or in embankment portion means the respective computations were followed. 
Equations for Hydraulic Analysis of Designed SSD system

In cutting portion the surface infiltration is, $\mathrm{q}_{\mathrm{i}}=0.50$ to 0.67 times of 1-hour / 1-year precipitation rate.

In embankment portion determination of surface infiltration by cadergren's method,

$$
\begin{gathered}
q_{i}=\frac{q}{w_{p}} \text { (8) } \\
q=0.1 \times\left(N+1+\left[\frac{w_{p}}{c_{s}}\right]\right)(9)
\end{gathered}
$$

Where, $\mathrm{q}_{\mathrm{i}} \& \mathrm{q}$ are surface infiltration \& inflow rate in, $\mathrm{m}^{3} / \mathrm{h} / \mathrm{m}$ and $\mathrm{w}_{\mathrm{p}}, \mathrm{N}, \& \mathrm{c}_{\mathrm{s}}$ are width in $\mathrm{m}$, number of lanes \& assumed spacing of transverse cracks of the pavement in, $\mathrm{m}$.

The inflow rate for longitudinal $\operatorname{drains}\left(\mathrm{q}_{\mathrm{L}}\right)$ and drainage layer $\left(\mathrm{q}_{\mathrm{g}}\right)$ were obtained from,

$$
\begin{aligned}
& q_{L}=2 \times\left(q_{1}+q_{2}\right) \text { in }, \text { in } \mathrm{m}^{3} / \text { day } / \mathrm{m}, \\
& q_{g}=\left[q_{1}+\left(\frac{2 q_{2}}{w_{p}}\right)\right] \text { in, } \mathrm{m}^{3} / \text { day } / \mathrm{m}, \\
& q_{1}=\frac{k\left(H-H_{0}\right)^{2}}{2 L_{i}} \text { in, } \mathrm{m}^{3} / \text { day } / \mathrm{m},
\end{aligned}
$$

Where, $\mathrm{q}_{1}=$ the inflow above the bottom of drainage layer, $\mathrm{q}_{2}=$ the inflow below the drainage layer.

$\mathrm{H}=$ initial height of the ground water table above the impervious layer, in $\mathrm{m}$,

$\mathrm{H}_{0}=$ vertical distance between the bottom of drainage layer and the impervious layer, in $\mathrm{m}$,

$$
\mathrm{Li}=\text { distance of influence }=3.8\left(H-H_{0}\right) \text { in, } \mathrm{m} \text {. }
$$

The design inflow of drainage layer $\mathrm{q}_{\mathrm{d}}$ to longitudinal drain,$\left(\mathrm{q}_{\mathrm{L}}\right)$ is obtained from,

$$
\begin{aligned}
& q_{d}=q_{i}+q_{g} \text { in, } \mathrm{m}^{3} / \mathrm{day} / \mathrm{m}, \\
& q_{L(\text { design })}=\left(q_{d} \times w_{p}\right)+q_{1} \text { in, } \mathrm{m}^{3} / \mathrm{day} / \mathrm{m},
\end{aligned}
$$

The one is must to understand about flow property is that, steady- state capacity of drainage layer, q is obtained from,

$$
q=k \times t_{b}\left[s+\left(\frac{t_{b}}{2 L}\right)\right] \text { in, } \mathrm{m}^{3} / \text { day } / \mathrm{m},(16)
$$

Where, $\mathrm{L}=$ length of the drainage layer, in $\mathrm{m}$.

It is necessary to determine the suitable diameter of perforated-corrugated pipe,(D), in inches, with respect to all analyzed hydraulic parameters, then the Manning's defines the diameter of the pipe (D) is,

$$
D=\left[\frac{n \times q_{L} \times L_{O}}{53 \times S^{0.5}}\right]^{0.375}
$$

Where, $L_{O}=$ outlet spacings which is obtained from Nomograph, in ft,

$$
L_{\text {O(actual) }}=\frac{53 \times S^{0.5} \times D^{2.667}}{q_{L} \times n} \text { in, m. (18) }
$$

And finally the discharge capacity of collector pipes can be calculated by Manning's formula (Full Flow Assumption),

$$
Q=86,400 \times\left(\frac{1.436}{n}\right) \times A \times R^{2 / 3} \times S^{1 / 2} \text { in, } \mathrm{m}^{3} / \mathrm{sec}(19)
$$

Where, $\mathrm{N}=$ roughness co-efficient for under drain perforated corrugated pipe, 0.020 ,

A=area of perforated pipe is, $\frac{\pi \times D^{2}}{4}$ in, $\mathrm{m}^{2}, \mathrm{P}=$ wetted perimeter is, $\pi \times D$ in, $\mathrm{m}, \mathrm{R}=$ hydraulic radius is, $D / 4 \mathrm{in}$, $\mathrm{m}$.

\section{Hydrological Computations to Estimate the Rainfall Potential}

Rainwater potential is calculated by using the value of total area and average rainfall for Hosur region and the formula is as follows;

\section{Rainwater Potential= Average Rainfall $\mathrm{x}$ Total area rainfall potential (20)}

\section{Formula for Water Available for Recharge and Expected Recharge}

a. Water available for recharge $=$ Area in $\mathrm{m}^{2} \mathrm{x}$ normal rainfall in $\mathrm{m} /$ year $\mathrm{x}$ runoff coefficient

b. Expected recharge $=75 \%$ of water available for recharge

\section{Design for Geo-Textile Material}

To get required Apparent Opening Size (AOS) of woven fabrics to retain the native soil particles into the drainage system, take average of $\mathrm{D}_{10}, \mathrm{D}_{30}, \mathrm{D}_{60}$ and $\mathrm{D}_{85}$ of collected samples and compute the Co-efficient of Uniformity $\left(\mathrm{C}_{\mathrm{U}}\right)$ and Co-efficient of curvature $\left(\mathrm{C}_{\mathrm{C}}\right)$ from gradation curve,

If, $\mathrm{CU}$ is lies between 4 to 8 then, $\mathrm{AOS} \leq \mathrm{D}_{85}$ avg

Actual AOS can be,

$$
\text { AOS }=B \times D_{85 a v g}
$$

$$
\text { Here, } B=8 / C_{U}
$$

\section{Results AND Discussion}

From the traffic study it was concluded that the stretch was classified under Heavy traffic road ( > $30 \mathrm{msa}$ ), because the cumulative no.of standard axles calculated in the design life ( $\mathrm{N}=15$ years) as per IRC-37-2007 is $51 \mathrm{msa}$. Hence excellent pavement performance under combined load of traffic with water load is very much essential. Annual Rainfall obtained 
from 10-year rainfall data is $914 \mathrm{~mm}$ approximately. Hence it is reveals that there is huge amount of storm water available for ground water recharge From our study it was observed that there were no sufficient number of culverts and the existing culverts were not properly connected to drainage ditch shown in Fig 9 \& Fig 10 respectively.

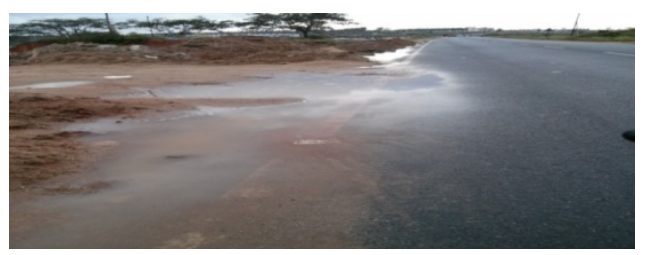

Fig. 9: Improper Construction of Shoulder and Water Stagnates along the Network

It was also observed that the shoulder width was inadequate and water logged areas along the stretch of the road. The embankment erosion was observed due to improper sloping. Hence, it is required to design the proper storm water drainage system on Hosur Inner Ring Road. Thus the conducted field surveys were reveals that, location for Recharge structures and suitable cross slope is 1 in 50 to 1 in 60 which is obtained from plotted Longitudinal and Cross sectioning of selected stretches. From the soil test conducted it was observed that soil is well graded sand with good drainage property with an average permeability of about 5.007 $\mathrm{x} 10^{-3} \mathrm{~cm} / \mathrm{sec}$ that indicates the soil is semi-pervious in nature. Table III shows the results of soil test.

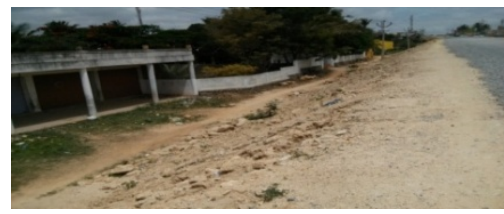

Fig. 10: Absence of Culvert Near Depressed Build-up Area

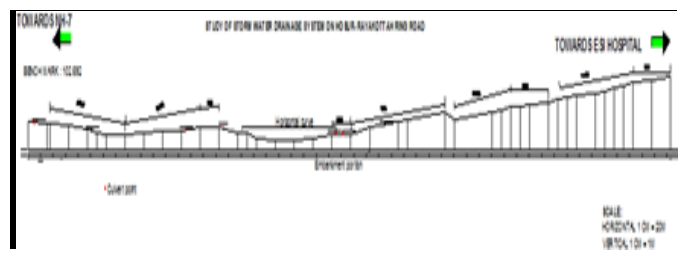

Fig. 11: Longitudinal Sectioning of Paved Stretch

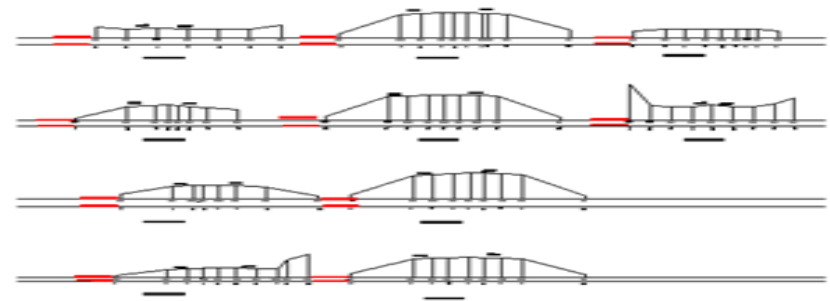

Fig. 12: Cross Sectioning of Paved Stretch

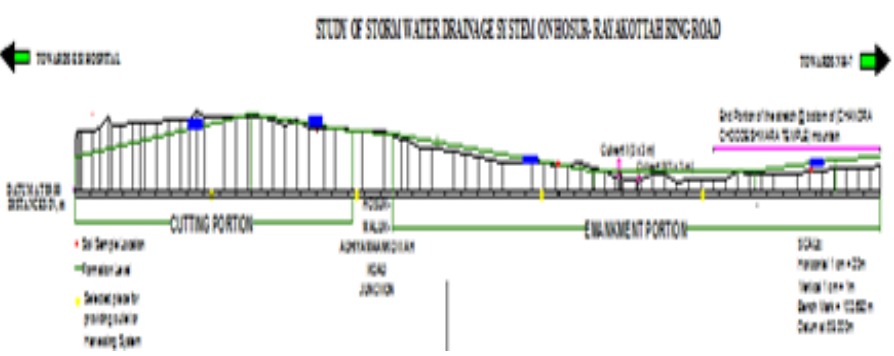

Fig. 13: Longitudinal Sectioning of Unpaved Stretch

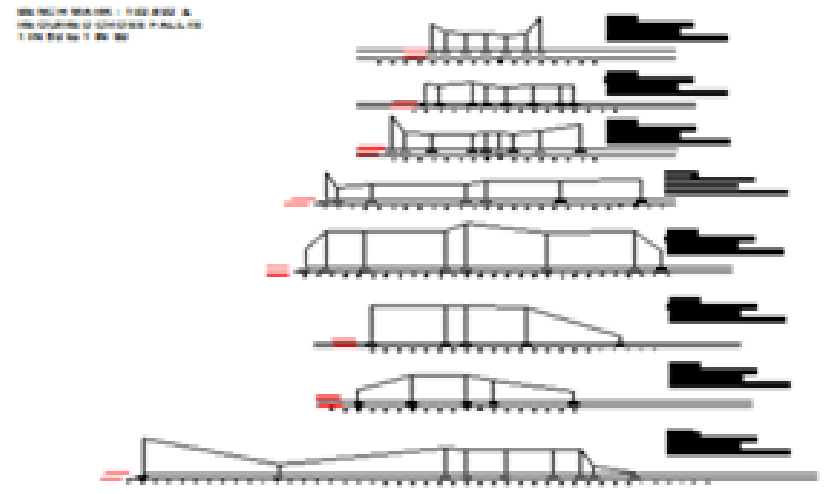

Fig. 14: Cross Sectioning of Unpaved Stretch

Table I: Shows the Collected 10-Year Rainfall Data of Hosur Region (2002 to 2012)

\begin{tabular}{|l|l|l|l|l|l|l|l|l|l|l|l|l|c|}
\hline YEAR & JAN & FEB & MAR & APR & MAY & JUN & JUL & AUG & SEP & OCT & NOV & DEC & TOTAL RAINFALL \\
\hline 2002 & 0 & 0 & 24 & 27.4 & 188.6 & 31 & 24.0 & 40.4 & 93.2 & 298.2 & 10.0 & 0 & 736.8 \\
\hline 2003 & 0 & 0 & 8.2 & 14.0 & 21.0 & 29.8 & 6.0 & 29 & 96.6 & 226.7 & 81.4 & 0 & 512.7 \\
\hline 2004 & 0 & 0 & 0 & 58.0 & 369 & 62.2 & 18.08 & 54 & 98.8 & 276.2 & 47.0 & 0 & 1146 \\
\hline 2005 & 0 & 0 & 15 & 54.0 & 90.2 & 44.0 & 0 & 57 & 237 & 495 & 147.1 & 30.7 & 1170 \\
\hline 2006 & 0 & 40 & 48 & 4.00 & 67.8 & 112.6 & 11.6 & 64.5 & 23.0 & 0 & 57.0 & 11 & 479.5 \\
\hline 2007 & 0 & 0 & 0 & 1034 & 59.0 & 83.0 & 57.0 & 100 & 99.0 & 195 & 33.0 & 69 & 1729 \\
\hline 2008 & 5 & 4 & 108 & 8.00 & 205 & 17.0 & 190 & 214 & 127 & 197.5 & 61.0 & 03 & 1139.5 \\
\hline 2009 & 0 & 0 & 11 & 30.0 & 167.4 & 58.0 & 24.0 & 116 & 186 & 13 & 141 & 14 & 760.4 \\
\hline 2010 & 0 & 0 & 0 & 0.0 & 168.1 & 45.7 & 72.2 & 72.6 & 104.4 & 81.6 & 172.7 & 4.5 & 721.8 \\
\hline 2011 & 0 & 0 & 0 & 0 & 170.9 & 37.2 & 76.1 & 69.4 & 129 & 72.8 & 172 & 5.2 & 732.6 \\
\hline 2012 & 0 & 0 & 8 & 0 & 160.6 & 42.8 & 56.5 & 97.4 & 132 & 79.2 & 154 & 5.5 & 736 \\
\hline
\end{tabular}


Table II: Shows the Gradient Details of Paved and Unpaved Stretch

\begin{tabular}{|l|l|l|l|l|}
\hline SL.NO & CHAINAGE & UP GRADIENT & DOWN GRADIENT & LEVEL \\
\hline 1 & $6100-6210$ & - & - & Level \\
\hline 2 & $6210-6660$ & - & 1 in 25.00 & - \\
\hline 3 & $6660-6710$ & - & - & - \\
\hline 4 & $6710-6850$ & 1 in37.33 & - & Level \\
\hline 5 & $6850-7000$ & - & 1 in 31.71 & - \\
\hline 6 & $7000-7117$ & 1 in 27.36 & - & - \\
\hline 7 & $7117-7145$ & - & - & Level \\
\hline 8 & $7145-7375$ & 1 in 36.05 & - & - \\
\hline 9 & $7375-7500$ & - & 1 in 36.05 & - \\
\hline 10 & $7500-7550$ & - & - & - \\
\hline 11 & $7550-7800$ & - & 1 in 25.00 & - \\
\hline 12 & $7800-8000$ & - & - & Level \\
\hline 13 & $8000-8155$ & 1 in 74.79 & - & - \\
\hline
\end{tabular}

Table III: Shows the Results of Soil Test

\begin{tabular}{|c|c|c|c|c|c|c|}
\hline SL.NO & SOIL TEST & SAMPLE -1 & SAMPLE - 2 & SAMPLE -3 & $\begin{array}{l}\text { AVERAGE } \\
\text { VALUE }\end{array}$ & REMARKS \\
\hline 1 & $\begin{array}{l}\text { Natural Moisture Content (NMC), } \\
\%\end{array}$ & 16.67 & 12.50 & 14.28 & 14.48 & - \\
\hline 2 & Specific Gravity(G) & 2.685 & 2.682 & 2.772 & 2.713 & Silty sands \\
\hline \multirow[t]{2}{*}{3} & \multirow[t]{2}{*}{ Dry Sieve Analysis } & $\mathrm{Cu}=5.375$ & $\mathrm{Cu}=6.785$ & $\mathrm{Cu}=6.153$ & $\mathrm{Cu}=6.104$ & \multirow{2}{*}{$\begin{array}{l}\text { Well graded sand(SW). } \\
\text { [According to USCS] }\end{array}$} \\
\hline & & Cc $=0.791$ & $\mathrm{Cc}=1.879$ & $\mathrm{Cc}=0.937$ & $\mathrm{Cc}=1.202$ & \\
\hline 4 & Permeability (K), cm/sec & $3.673 \times 10^{-3}$ & $7.106 \times 10^{-3}$ & $4.244 \times 10^{-3}$ & $5.007 \times 10^{-3}$ & $\begin{array}{l}\text { Fine sands or loose silt \& drainage property } \\
\text { is FAIR }\end{array}$ \\
\hline \multirow[t]{2}{*}{5} & \multirow[t]{2}{*}{$\begin{array}{l}\text { Standard Proctor Test for, MDD \& } \\
\text { OMC }\end{array}$} & $\begin{array}{l}\mathrm{MDD}=1.879 \\
\mathrm{gm} / \mathrm{cc}\end{array}$ & $\begin{array}{l}\mathrm{MDD}=1.815 \\
\mathrm{gm} / \mathrm{cc}\end{array}$ & $\begin{array}{l}\mathrm{MDD}=2.004 \\
\mathrm{gm} / \mathrm{cc}\end{array}$ & $\begin{array}{l}\mathrm{MDD}=1.899 \\
\mathrm{gm} / \mathrm{cc}\end{array}$ & $\begin{array}{l}\text { Well graded sand } \\
1.8 \text { to } 1.9 \mathrm{gm} / \mathrm{cc} \\
\end{array}$ \\
\hline & & $\mathrm{OMC}=12 \%$ & $\mathrm{OMC}=14 \%$ & $\mathrm{OMC}=10 \%$ & $\mathrm{OMC}=12 \%$ & Sandy silts or Silty sands(8-12\%) \\
\hline
\end{tabular}

\section{A. Design of Storm Water Drainage System}

The unpaved stretch of $1 \mathrm{~km}$ were selected to study the soil characteristics and to design the sub-surface drainage system which consists one for each category that is Horizontal curve( $\mathrm{km}$ 7100to7410), Cutting section (km 7155to7500),and Embankment section(km 7550 to 8155).Figure 1 \&Figure 2 shows the details of study are a map. The design part was taken up for all three categories. Hydrological and Hydraulic parameters were considered for the design of storm water drainage system. The amount of Run-off available for recharge was estimated from the rainfall data collected. The drainage system is primarily concerned with saturated gravity flow, which is determined by application of Darcy's law. To understand and analyze the conditions under which the pavement must function, The information needs on highway geometrics, surface drainage, non-pavement subsurface drainage, climate, and soil properties.

Hydraulic design for sub-surface drainage system were considered between the chain age of km7/155 tokm8/155.The basic method considers subsurface drainage layers as conveyors of water and analyzes probable inflow rates from all known important sources. Seepage principles are then used to determine the required permeability and thickness of a sub-surface drainage layer that will accommodate the anticipated flows.The1hour/1year precipitation data were calculated from collected 10 year rainfall data shown in Table I and required permeability for drainage layer and trench was calculated from obtained Family and Group curves. Finally the pipe diameter and outlet separations were selected from nomograph with the aid of pipe gradient and width of the pavement. The designed SSDs were analyzed for Hydraulic properties by selected equations of Manning's and Cadergren's formulae's.

The details of the expected recharge available per annum is shown in Table IV and Hydraulic design for sub-surface drainage system were considered between the chainage of 7155 to 8155 . The designed values for sub-surface drainage system was tabulated in Table $\mathrm{V}$ and sub-surface drainage system was plotted using AUTO-CADD. The AOS (Apparent Opening Size) of the geo-textile material is 1.119 to $3.46 \mathrm{~mm}$ and Figure 15, 16, 17 and 18 shows the Cross sectional details of subsurface drainage system of all selected portions individually. However the collected storm water may effectively recharges the nearby ground water level with proper conveying arrangements which is shown in Figure 19 \& 20

Table IV: The Run-Off for Recharge into Recharge Trench

\begin{tabular}{|l|l|l|}
\hline \multicolumn{1}{|c|}{ Area type } & Pavement & \multicolumn{1}{|c|}{$\begin{array}{c}\text { Paved area } \\
\text { (Embankment } \\
\text { side slopes) }\end{array}$} \\
\hline Area in $\mathrm{m}^{2}$ & 12,000 & $8,549.180$ \\
\hline Normal rainfall in m/year & 0.914 & 0.914 \\
\hline Runoff co-efficient & 0.80 & 0.85 \\
\hline $\begin{array}{l}\text { Total rainfall available in } \\
\mathrm{m}^{3} / \text { Annum }\end{array}$ & $8,774.40$ & $6,641.85$ \\
\hline Run-off at hourly rainfall intensity & 573.677 & 434.249 \\
\hline \multicolumn{2}{|c|}{ Estimated runoff available for recharge } \\
\hline Run-off collected area & $20,549.180 \mathrm{~m}^{2}$ \\
\hline Run-off available for recharge & $15,416.258 \mathrm{~m}^{3} / \mathrm{annum}$ \\
\hline $\begin{array}{l}\text { Expected run-off at hourly rainfall } \\
\text { intensity }\end{array}$ & $1,007.926 \mathrm{~m}^{3}$ \\
\hline $\begin{array}{l}\text { Expected run-off available for } \\
\text { recharge }\end{array}$ & $11,550 \mathrm{~m}^{3} / \mathrm{annum}^{3}$ \\
\hline
\end{tabular}




\section{B. Future Enhancement}

A clear indicator of the cost and benefits of maintenance is needed. If the system was constructed throughout the highway network the, national and local training programs for construction and maintenance personnel are needed to improve drainable pavement performance. Although not identified as a significant research need in the survey, the structural contribution of permeable base to the pavement section is not fully understood and needs further study. More study is also required to evaluate the effectiveness of permeable base compared with that of dense-graded base for asphaltic pavement and needs in depth study of suitable Recharging structure with the aid of detailed Geological survey. Design guidelines are needed to determine when construction of a drainage system with Recharging structure is cost-effective for special climatic conditions (e.g., arid and semi-arid climates with significant snow melt and the positive and negative effects during freeze-thaw events).

The team approach, in which all functional groups are involved in making design, construction, and maintenance decisions, is introduced in this synthesis as a method to fully evaluate and establish the most appropriate subsurface drainage strategy. The team approach may appears to be the best method for obtaining true life-cycle cost-benefit assessment of drained and un drained pavements systems and for providing the information necessary for continuous improvements on constructed SSDs

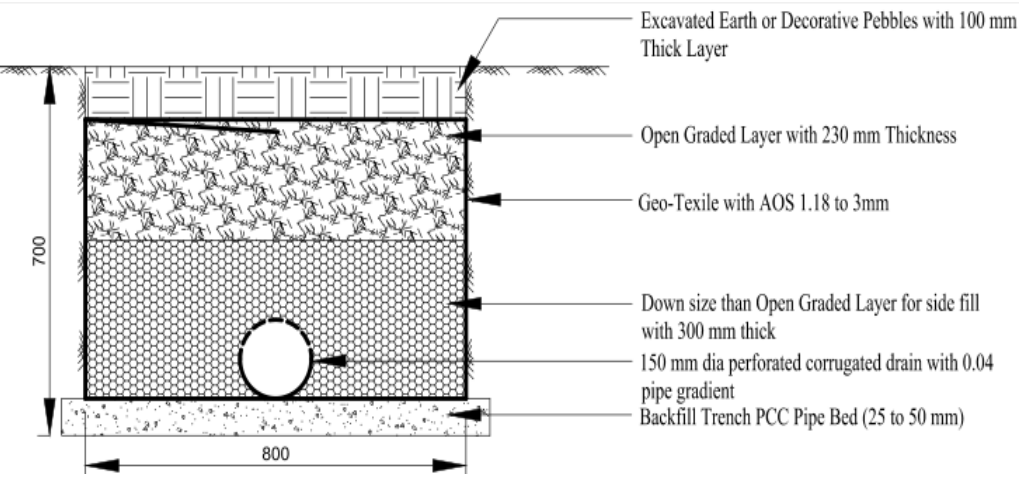

Fig. 15: Cross Sectional View of Collector Trench for Cutting Portion (CH:7155 to 7500)

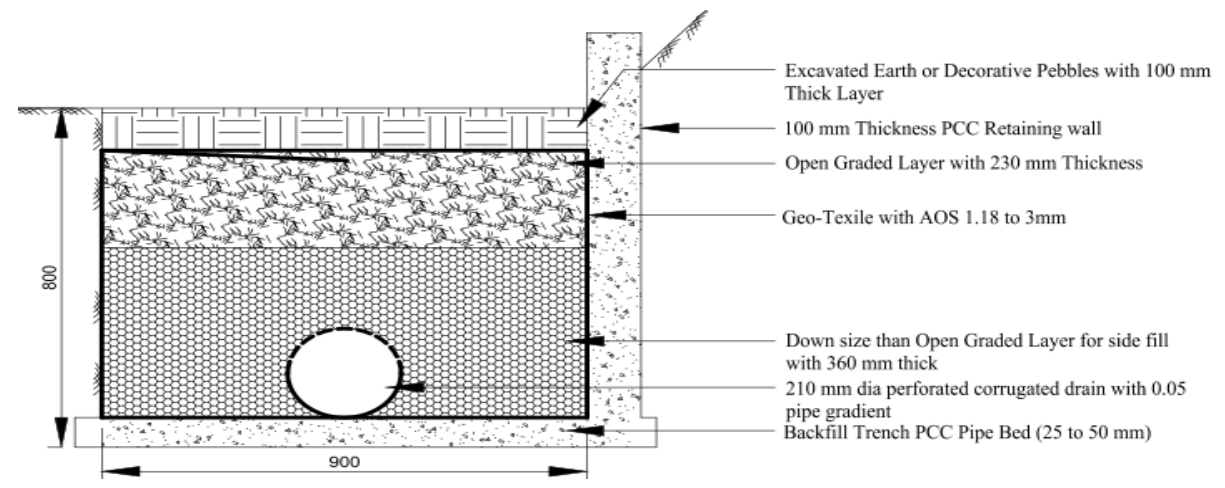

Fig. 16: Cross Sectional View of Collector Trench for Embankment Portion (CH:7550 to 8155)

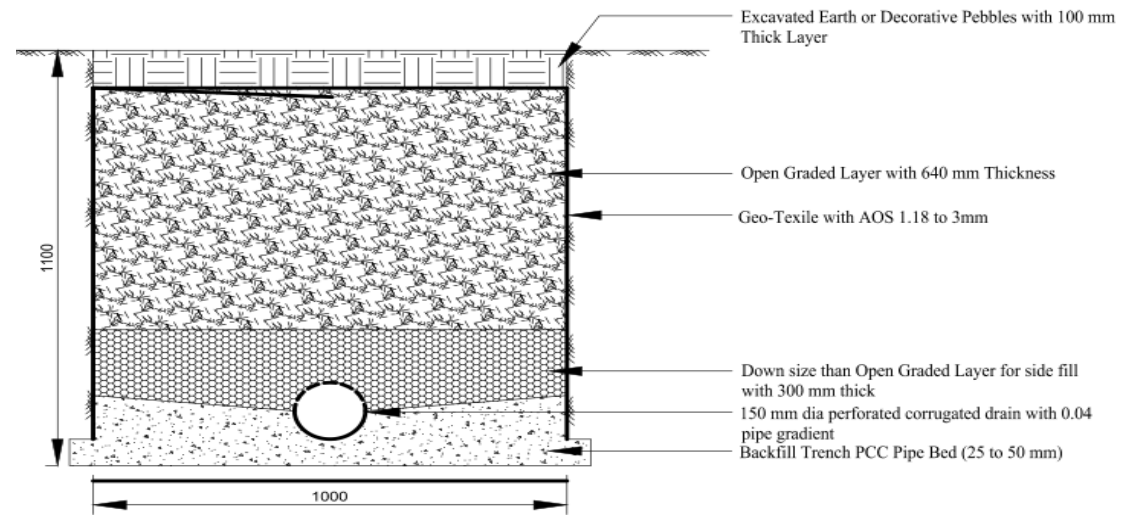

Fig. 17: Cross Sectional View of Collector Trench for Transition Curve Portion 


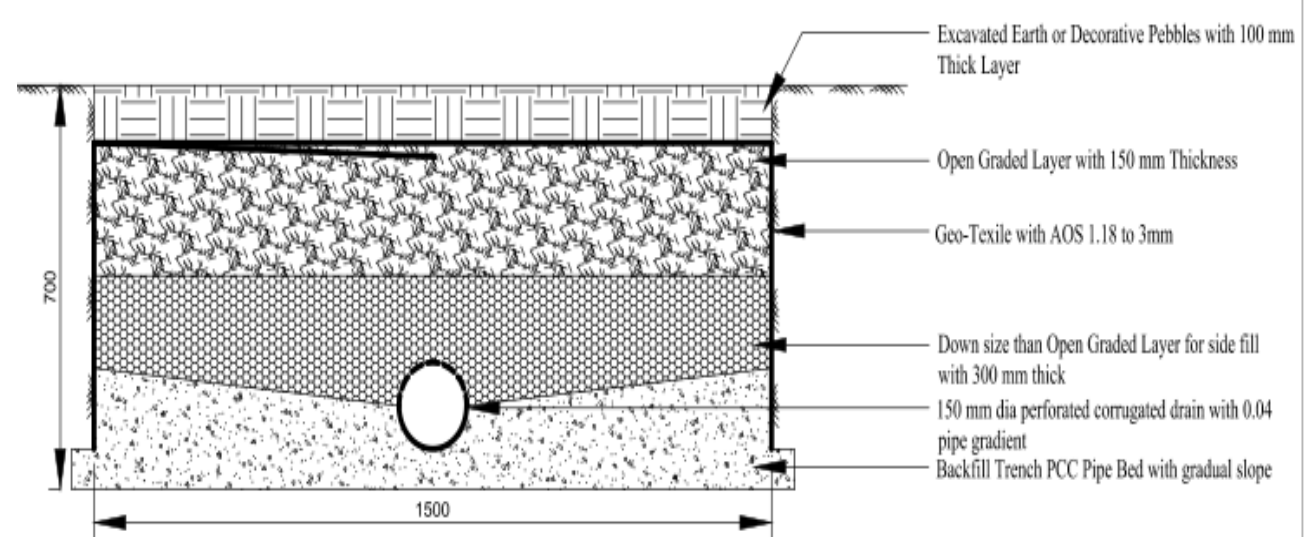

Fig. 18: Cross Sectional View of Collector Trench For Inner Side of Super Elevated Portion (CH: 7100 to 7410)

Table V: The Details of Designed Sub-Surface Drainage System

\begin{tabular}{|c|c|c|c|c|}
\hline Description & \begin{tabular}{|l|} 
Cutting portion \\
(CH:7155 to 7500$)$ \\
\end{tabular} & $\begin{array}{l}\text { Embankment portion } \\
\text { (CH:7550 to 8000) }\end{array}$ & $\begin{array}{l}\text { Embankment portion } \\
\text { (CH:8000 to 8155) }\end{array}$ & $\begin{array}{l}\text { Super elevation } \\
\text { (CH:7100 to } 7410)\end{array}$ \\
\hline $\begin{array}{l}\text { 1hr/1yr Precipitation, } \\
\text { inches / hr }\end{array}$ & 0.411 & 0.411 & 0.411 & 0.411 \\
\hline $\begin{array}{l}\text { Ground water inflow, } \mathrm{I}_{\mathrm{G}} \\
\text { inches } / \mathrm{hr}\end{array}$ & 3.9765 & - & - & 3.9765 \\
\hline $\begin{array}{l}\text { Thickness of open graded } \\
\text { layer, } t_{b} m\end{array}$ & 0.230 & 0.230 & 0.230 & $\begin{array}{l}640 \mathrm{~mm} \text { for transition } \\
\text { curves and } 150 \mathrm{~mm} \text { for } \\
\text { super elevation portion }\end{array}$ \\
\hline $\begin{array}{l}\text { Co-efficient of } \\
\text { permeability of open } \\
\text { graded layer }(T=1 \mathrm{hr}) \text {, } \\
\mathrm{k}_{\mathrm{b}, \mathrm{m}} \text { /day }\end{array}$ & $3,658.536$ & $1,926.829$ & $1,926.829$ & $\begin{array}{l}\text { 597.506 for transition } \\
\text { curve portion and } \\
3,272.09 \text { for super } \\
\text { elevation portion }\end{array}$ \\
\hline $\begin{array}{l}\text { Time to drain open } \\
\text { graded layer } \mathrm{T}, \mathrm{hr}\end{array}$ & 0.391 & 0.736 & 0.734 & $0.22 \mathrm{hrs}$ \\
\hline Pipe diameter $\mathrm{d}, \mathrm{mm}$ & 150 & 210 & 150 & 150 \\
\hline Outlet separation $\mathrm{L}_{\mathrm{O}}, \mathrm{m}$ & 350 & 380 & 350 & 350 \\
\hline $\begin{array}{l}\text { Minimum permeability } \\
\text { required for collector } \\
\text { trench } k_{t}, \mathrm{~m} / \text { day }\end{array}$ & 707.231 & 66.827 & 66.827 & $1,214.170$ \\
\hline $\begin{array}{l}\text { Collector trench width B, } \\
\text { m }\end{array}$ & 0.80 & 0.90 & 0.80 & $\begin{array}{l}0.95 \mathrm{~m} \text { for transition and } \\
1.54 \text { for super elevation } \\
\text { portion }\end{array}$ \\
\hline Pipe gradient \% & 0.04 & 0.05 & 0.02 & 0.04 \\
\hline $\begin{array}{l}\text { Design inflow to } \\
\text { drainage layer } \mathrm{q}_{\mathrm{d}}(\text { design}) \text {, } \\
\mathrm{m}^{3} / \text { day } / \mathrm{m}\end{array}$ & 0.735 & 0.735 & 0.735 & 0.735 \\
\hline $\begin{array}{l}\text { Design inflow to } \\
\text { longitudinal drains } \mathrm{q}_{\mathrm{L}} \\
\text { (design), } \mathrm{m}^{3} / \mathrm{day} / \mathrm{m}\end{array}$ & 5.0748 & 5.0748 & 5.0748 & 5.0748 \\
\hline $\begin{array}{l}\text { Discharge capacity of } \\
\text { collector pipe }, \mathrm{m}^{3} / \text { day }\end{array}$ & $1,782.818$ & $4,123.989$ & $1,782.818$ & $4,123.989$ \\
\hline
\end{tabular}




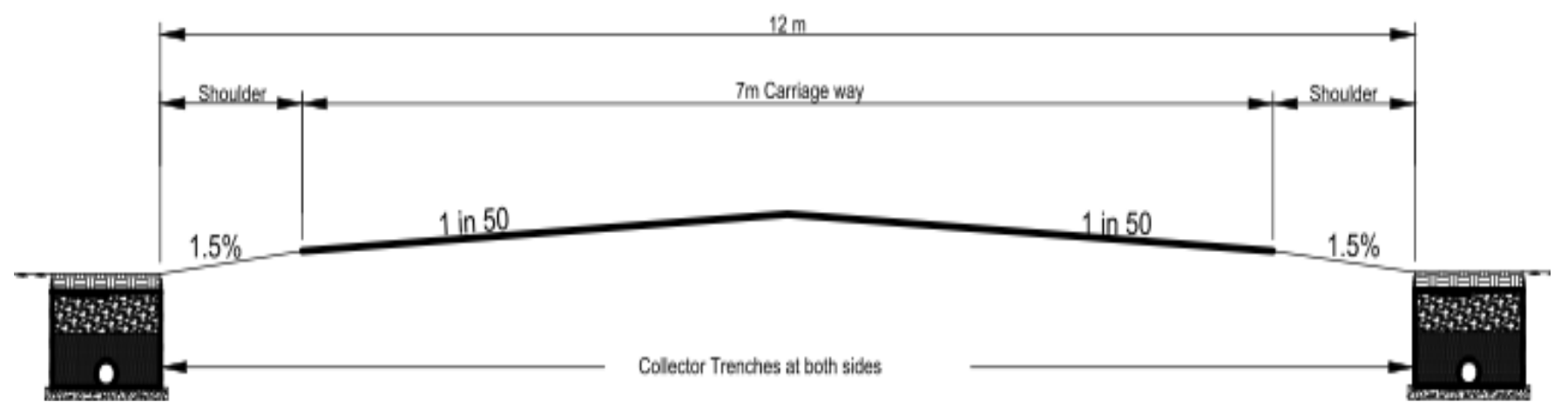

Fig. 19: Cross sectional View of Location for Collector Trench in Cutting Portion (CH:7155 to 7500)

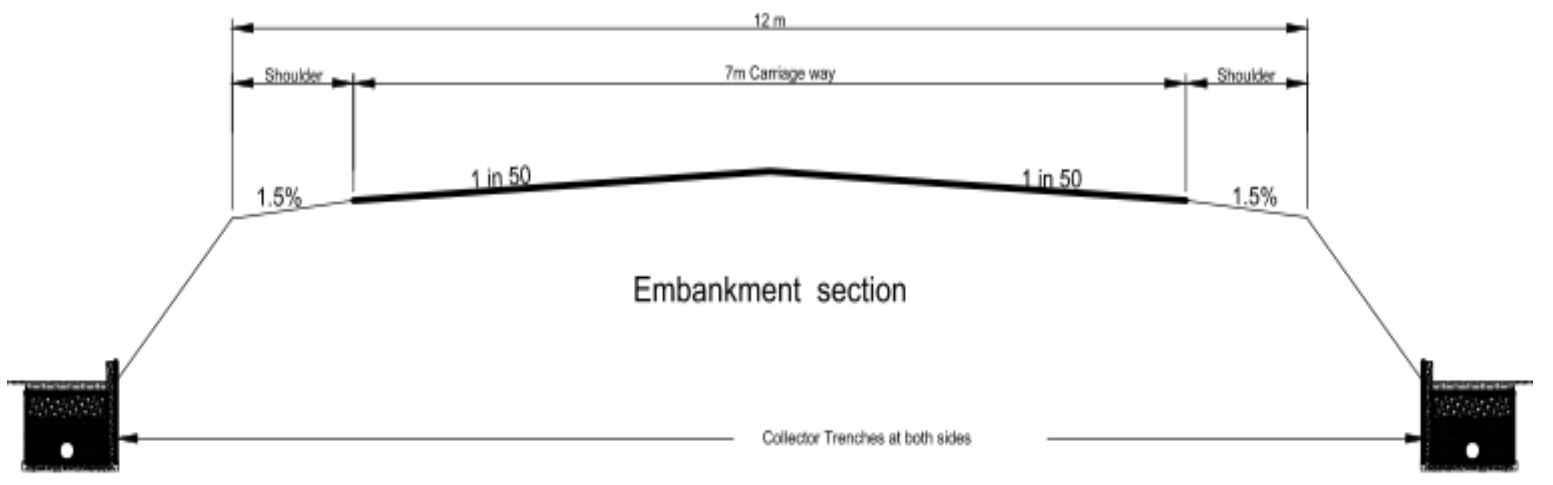

Fig. 20: Cross sectional View of Location for Collector Trench in Embankment Portion (CH:7500 to 8000)

\section{CONCLUSIONS AND RECOMMENDATIONS}

\section{A. Conclusions}

From our study it can be concluded that,

- The observations that many pavements are subject to moisture-related problems has convinced many engineers that subsurface drainage design criteria and principles should be part of the pavement structural procedure.

- $\quad$ The sag points are at Chainages 7155,7800 and 8000 so the recharge structures / trenches are to be provided at those locations and the cross slopes varies 1 in 50 to 1 in 60 throughout the selected stretch.

- $\quad$ From laboratory study the soil is classified as well graded sand with good drainage property and Semipervious in nature

- The amount of rainwater that can be harvested for Chainage 7155 to 8155 is $15,416.258 \mathrm{~m}^{3} / a n n u m$ and the expected amount of rain water that can be Recharged for our stretch is $11,550 \mathrm{~m}^{3} /$ annum.

- The design of subsurface drainage system for pavement structures reveals that, the design is not difficult, but it is site- specific.

- By using this sub-surface drainage system runoff from pavement can be reduced and the ground water can be enhanced by using suitable recharge structures.

\section{B. Recommendations}

- Proper care should be given to the surface and subsurface drainage of pavement during and after construction of the pavement.

- Geotextile separator/ filters usually have the lowest material cost and allow for a full-depth permeable base to be used; however, they do not increase pavement support as do dense-graded aggregate separator/filters. Therefore, a design effort is required to identify when and where these filters are to be used.

- Pavement deterioration model should be developed including drainage parameter.

- Periodic maintenance and inspection of the subsurface drainage system should be carried out and stretches where water stagnates either in the side drain or on the pavement surface should be identified for immediate corrective measures.

\section{REFERENCE}

[1] Rocade.S, Agerwall P.K \&Shrivastava.R, "Study on Drainage Related Performance of Flexible Highway Pavements", International Journal for Advanced Engineering \& Technology, vol.4., Issue no.4., pp:334-337., 2012(January-March).

[2] Florian Zamfirescu, Iulian Papa, AlexandruDanchi , "Gravitational Drainage Systems in Urban Areas Case Study Galati Town, Romania”, RMZ, Materials and Geo-Environment Vol.50, Issue No.1., pp:435-438., 2003. 
[3] Ahmadi.Z, Gh.Agrani, "Hydraulic Condition of Sub-Surface Drainage System (Case Study, Sari, Iran)”, International Journal of Agriculture \& Crop Sciences. Vol.5., Issue no.6.,2013

[4] Prashant Kumar Azad, YogeshU.Shah, S.S.Jain, M.Parida (2013), "Estimating the Benefits of Improved Drainage on Pavement Performance”, International Journal of Engineering and Technology Vol.5, No.3 pp:78-92.2013

[5] Dr.K.R.Arora Soil Mechanics and Foundation Engineering, 7th edition(Reprint 2011), standard publishers distributors New Delhi110006, 2011.

[6] Yang H.Huang, Pavement Analysis and Design, Second edition, Dorling Kindersley (India) Pvt.Ltd., licensees of pearson education in South Asia.

[7] Jerome A. Westpal, Storm Water Collection Systems Design Hand Book(2004), Chapter 4: Hydrology for Drainage System Design \& Analysis., The McGraw-Hill Companies, 2004.

[8] Cedergren/Koa A joint venture Sacramento and long beach, California (June 1972), Development of Guidelines for the Design of Subsurface Drainage System for Highway Pavement Structural Sections, Federal Scientific and Technical Information , Spring field Virginia-22151, 1972.

[9] IRC-SP-20 (February, 2002), Rural Roads Manual The Indian Road Congress, New delhi-110011, 2002.

[10] IRC-SP-42 (September, 1994), Guidelines for Road Drainage The Indian Road Congress, New delhi-110011, 1994.

[11] G.J.Mulder, C.J.L.M.Luijein\&C.P.Schouten, “Case Study: Modeling The Impact of Drainage System Along a Depressed Roadbed and the Resulting Risks to Agriculture”, Failure Groundwater Resources of Risk (Proceedings of The Conference),IAHS publications, pp:61-70.,June1994

[12] Sung-Joon HONG, Takadhi OGUCHI, "Evaluation of Highway Geometric Design \& Analysis of Actual Operating Speed”, Journal of the Eastern Asia Society for Transportation Studies, vol.6., Issue No.4., pp:1048-1061., 2005.

[13] DagnachewAdugnaBelete, "Road and urban stormwater drainage network investigation in Addis Abada: Addis Ketemasubcity”, Journal of Engineering and Technology Research, vol. 3 (7), pp:217-225, July, 2011

[14] G.Shailendra and A.Veeraragvan, "Reseach need in subsurface drainage for Long Lasting pavements”, Highway Research Journal, 2010

[15] H.R.Cedergren, "Why all important pavements should be well drained", Transportation Research Record,1188. pp 56-62, 1998

[16] S.H.Carpenter, "Highway Subdrainage Design by Microcomputer (DAMP), Drainage analysis and modeling programs”, Publication No IP 090-012, Washington D.C, pp 144-145,1999

[17] H.R.Cedergren, "Drainage of Highways and Airfield pavements", wiling inter science publications, Newyork, 1974

[18] National Committee on Irrigation and Drainage, "Underground Drainage, Planning”, pp 26, exploitation 254, 2007

[19] Stust LCPM, W.Dierix, B.Matinez, "Materials for subsurface land drainage system”, FAO Irrigation \& Drainage, Paper.no:6,pp 183, 2000

[20] M.Bybordi, "Principles of drainage engineering and land reclamation", $8^{\text {th }}$ ed, Uniersity of Tehran, published in Persian,1999

[21] Ron Corley, AnberMerra, Lori Faha, Amanda Fritz, "Stormwater/Pavement Impacts Reduction (SPIR)-Project Report”,Adubon Society of Portland, Summer 2004

[22] The Low Impact Development Center, "Evaluation of Best Management Practices for Highway Runoff Control-Low Impact Development Design manual for Highway runoff control”, University of Florida, 2006

[23] L.G.Swain, P.Eng, "Evaluation of Storm Drainage from Highway 97 to Okanangan Lake of Kelowna B.C-Working Report", Ministry of Environment, 1982

[24] G.P.Raymond, R.J.Bathrust, J.Hajek, "Evaluation and Suggested Improvements to Highway edge drains incorporating Geotextiles”, 1999

[25] Roderick J. Fyfe, "Subsoil Pavement Drains-Panel Drains Vs Round pipe comparison".

\section{BIOGRAPHY}

Dr.L. Yeshodha received the B.E degree in Civil (Transportaion) Engineering from Bangalore university, Bangalore, Karnataka in 1988.The M.E degree in Water Resources Engineering from Bangalore university,
Bangalore, Karnataka in 1997 and the Ph.D degree in Civil Engineering from Anna University, Chennai, Tamilnadu.

Currently is a PROFESSOR of Civil Engineering department at Adhiyamaan College of Engineering, Hosur, Tamilnadu. Her teaching and research area includes Hydraulics, Water Resources Engineering and Transportation Systems. Dr.L.YESHODHA, Professor may be reached at yesocivil123@yahoo.co.in

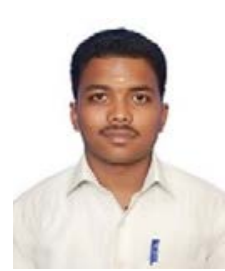

Er.KR. Manikandan received the B.E degree in Civil Engineering from Anna University-Chennai, through Adhiyamaan College of Engineering, Hosur , Tamilnadu, INDIA in 2014.

He worked as a Guest Lecturer in Civil Engineering department at Alagappa Polytechnic College (Govt.,), Karaikudi, Tamilnadu. And Currently is a ASSISTANT ENGINEER (In-charge) in Department of Quality Assurance and Quality Control at Sai Care India Private Limited, Chennai, Tamilnadu. His research area includes, Geo-technical Engineering, Water Resources Engineering and Transportation Engineering. Er.KR.MANIKANDAN, Assistant Engineer may be reached at belleyedancivilian.1793@gmail.com 